\title{
The Binding of Sodium Nitroprusside with Albumin Using Square Wave Voltammetry
}

\author{
Saddalah T. Sulaiman \\ Department of Chemistry \\ College of Science \\ University of Mosul
}

Mohammed M. Al-Imam

Department of Chemistry

College of Education

University of Mosul

E.mail :mohammedalimam@yahoo.com

(Received 19/4/2011;Accepted 31/10/2011)

\begin{abstract}
The voltammetric behavior of pure Sodium Nitroprusside was studied in a direct method in aqueous phosphate solution at $(\mathrm{pH}=7.0)$ by square wave voltammetry Sodium Nitroprusside gives a well defined square wave voltammetric peak at $(-0.592)$ volt against the reference electrode $(\mathrm{Ag} / \mathrm{AgCl} / \mathrm{SatKCl})$. The calibration curve is linear within the range of concentration $\left[\left(0.398 \times 10^{-6}\right)-\left(8.424 \times 10^{-6}\right)\right]$ molar with a correlation coefficient of (0.9991). The binding of Sodium Nitroprusside with Albumin has been studied, the binding constants $(\mathrm{K})$ were calculated at different temperatures. Vant's hoff equation applied to calculate the thermodynamic variables $(\Delta \mathrm{G}, \Delta \mathrm{S}, \Delta \mathrm{H})$, and the results indicate that the binding of SNP with albumin is of the type (ion-ion).
\end{abstract}

Keywords: Binding, sodium Nitroprusside, albumin, square wave voltammetry.

\section{النرالبا لنيتروسوسيد الصويوهمع الألبومبن بلستخدلم فولتامتري الموجة المربهة}

\section{المالمص}

تمت درلسة الخواص الفولتلمترية للنيتروبروهد يد ال مصوديوم (Sodium Nitroprusside) الق مي

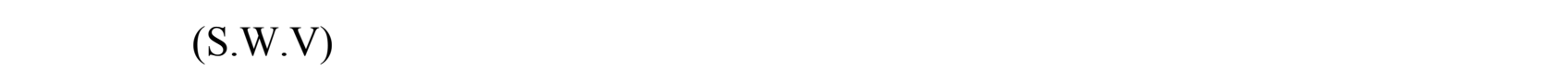

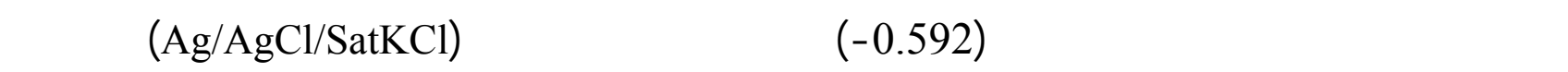

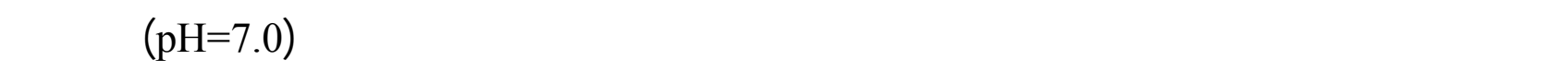

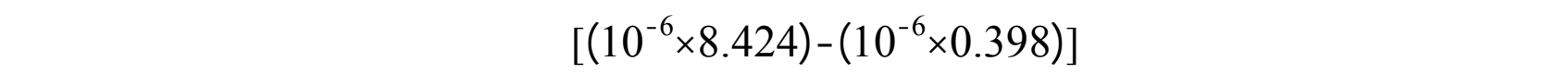
.(0.9991)

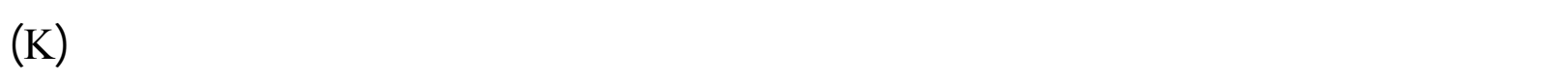

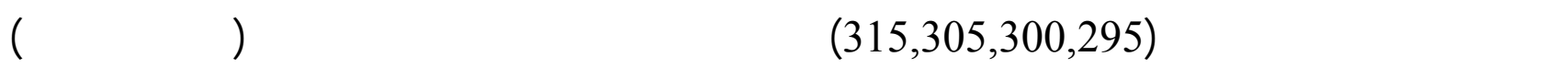

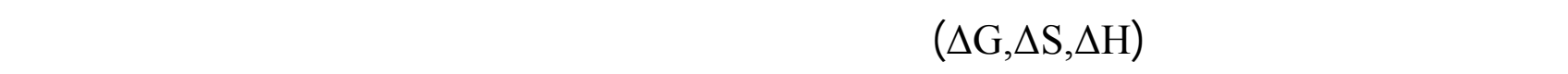

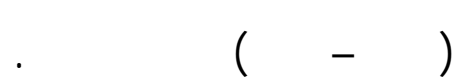
الكاملت الدالة: الترالط، ونيتروبروسيد الصوديوم، الألبومين، فولتلمتري الموجة المربعة. 


\section{INTRODUCTION}

Sodium mitroprusside (SNP) is the chemical compound with the formula $\mathrm{Na}_{2}\left[\mathrm{Fe}(\mathrm{CN})_{5} \mathrm{NO}\right] \cdot 2 \mathrm{H}_{2} \mathrm{O}$ as shown in Fig. 1. This salt serves as a source of nitric oxide, a potent peripheral vasodilator that affects both arterioles and venules (venules more than arterioles) (Butler, 2002). SNP is often administered intravenously to patient who are experiencing a hypertensive emergency. The principal pharmacological action of SNP is to relax a smooth muscle and consequent dilatation of peripheral arteries. Dilatation of the coronary arteries also occurs (Coppens, 2002). SNP has been suggested to cause cytotoxicity through either the release of cyanide and or nitro oxide, iron moiety of break down product of SNP could cause a long lasting oxidation stress,such as hydroxyl radical generation, lipid peroxidation and cytotoxicity (Navaza, 1989) (Rauhala, 2005). This drug can cause very large decreases in blood pressure. With out proper monitoring of serious injury, death could result. Nitroprusside, especial largerthan-recommended doses, might cause cyanide poisoning (Medicinenet, 2011) (Medicines, 2004).

Several methods are available for measuring SNP.The spectrophotometric method of analysis for SNP developed utilizing the molar absorptivity values at the maxima appearing in the electronic spectrum at 394 and $498 \mathrm{~nm}$. These measurements appear to be indicative of the unaltered nitro ferricyanide complex. A reaction sequence is postulated for aqueous solutions of nitroprusside exposed to normal artificial light (Frank, 1976). A rapid high performance chromatographic method for the determination of nitroprusside in commercial lyophilized product or in intravenous admixture solutions is described. Phenyl colum with a mobile phase acetonitrile-phosphate/tetrabutyl ammonium hydroxide buffer $(\mathrm{pH}=7.1)$ $(30: 70)$ and detection at $210 \mathrm{~nm}$ is worded out. Acoefficient of variation of better than $3.1 \%$ was achieved over the concentration range studied $(10-50 \mu \mathrm{g} / \mathrm{ml})$ and the total analysis time was 9 minutes (Baaske, 1981). The electrochemical reduction of the nitroprusside ion (NP) was examined by (DPP) and (SWV) The effect of $\mathrm{pH}$ on the electro chemical behaviour of (NP) was studied and experimental evidence for the occurrence of adsorption of the product of the first one-electron reduction of (NP)is shown.Owing to the adsorption of these products, which are the reactants in the second reduction step of NP, the peak current of the second process is highly enhanced compared with that of the first process,especially at low concentration levels $\left(<1 \times 10^{-5} \mathrm{~mol} / \mathrm{dm}^{-3}\right)$. Square-wave cathodic voltammetry with adsorptive accumulation was used for the determination of NP. The detection limit depends on the square wave parameter and can be as low as $\left(2.3 \mathrm{nmol} / \mathrm{dm}^{-3}\right)$ for a delay time of $60 \mathrm{sec}$ (Helena, 1996).

The present work involves the use of square wave voltammetric method for trace determination of SNP and studying the molecular interaction with albumin.

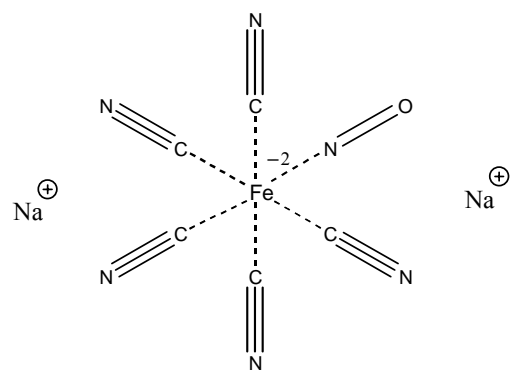

Fig. 1 :Chemical structure of sodium nitroprusside M. wt $=298 \mathrm{gm} / \mathrm{mole}$. 


\section{Apparatus}

\section{EXPERIMENTAL}

All experiments were performed using the EG and G PAR 384 B computerized polarographic analyser equipped with 303 A hanging mercury drop electrode and RE 0093 digital Plotter. A three electrode system was used. The working electrode was (HMDE); the reference electrode was $\mathrm{Ag} / \mathrm{AgCl}$, sat $\mathrm{KCl}$ electrode and the counter electrode was a Pt-wire electrode. $\mathrm{pH}$ measurement were made using PW 9421-Philips $\mathrm{pH}$-meter. Temperature control was made by using Haake NK 22 water thermostate $( \pm 0.1 \mathrm{C})$.

\section{Reagents}

All the chemicals used were of analytical reagent grade. SNP which were obtained from Fluka. Solutions of $1.0 \times 10^{-3} \mathrm{M}$ were prepared with deionised distilled water. Bovine serum albumin (BSA) was obtained from Merck, 0.1\% solution was freshly prepared. Phosphate buffer was prepared by mixing certain amounts of $0.2 \mathrm{M}$ of each of $\mathrm{K}_{2} \mathrm{HPO}_{4}$ and $\mathrm{KH}_{2} \mathrm{PO}_{4}$.

\section{Procedure}

The voltammetric cell was thermostated at $37 \mathrm{C}^{\circ}$, the solution was de-aerated by passing through it a slow stream of purified nitrogen gas for 10 minutes for removing the dissolved oxygen. The square wave voltamogram was recorded on a degassed phosphate buffer solution at $(\mathrm{pH}=7.0)(5 \mathrm{ml})$. The blank current was recorded. Appropriate amount of SNP stock solution was added to this solution to yield the desired concentration and the current -voltage current was recorded again. The calibration curve was then constructed. The same procedure was also used to calculate the binding constant $(\mathrm{K})$, using the optimum conditions in Table 1. For voltammetric measurements, the sample cell contained (5ml) of phosphate buffer at $(\mathrm{pH}=7.0)$ with a final concentration $\left(9.9 \times 10^{-6}\right) \mathrm{M}$ of SNP. The square wave voltamogram was recorded to give the SNP peak.Then, appropriate amount of $\left(10^{-5}\right)$ $M$ of albumin was added to the cell and the square wave voltamogram were recorded at different temperatures in the range (295-315) $\mathrm{K}^{\circ}$ in order to calculate the thermodynamic quantities $\Delta \mathrm{G}, \Delta \mathrm{S}$ and $\Delta \mathrm{H}$.

\section{RESULTS AND DISCUSSION}

Typical square wave voltamogram of $\left(7.578 \times 10^{-6}\right) \mathrm{M}$ SNP in phosphate buffer at $(\mathrm{pH}=7.0)$ is shown in Fig. 2.

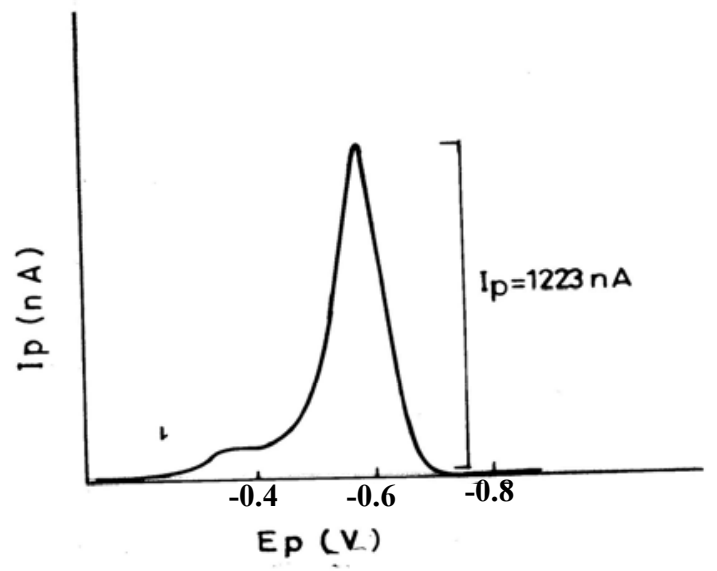

Fig. 2: Square wave voltamogram of $\left(7.578 \times 10^{-6}\right) \mathrm{M} \mathrm{SNP}$ at $(\mathrm{pH}=7.0)$. 
It can be seen from Fig. 2, that a well-defined peak appeared at $(-0.589 \mathrm{~V})$ versus ( $\mathrm{Ag} / \mathrm{AgCl}, \mathrm{Sat} \mathrm{KCl})$ electrode.

\section{Optimum conditions}

The SWV voltamogram of $\left(1.96 \times 10^{-6}\right) \mathrm{M}$ of SNP was investigated in phosphate buffer $(\mathrm{pH}=7.0)$ by variation all the parameters of the measurements, the optimum values obtained are tabulated in Table 1.

Table 1: The optimum values obtained which give either the highest peak current or the best resolution of the peak.

\begin{tabular}{|c|c|c|c|}
\hline Condition & Value & Condition & Value \\
\hline initial pot. & $-0.1 \mathrm{~V}$ & frequency & $120 \mathrm{~Hz}$ \\
\hline final pot. & $-0.85 \mathrm{~V}$ & scan increment & $2 \mathrm{mV} / \mathrm{sec}$ \\
\hline deposition time & 40 second & cond. potential & $\mathrm{V} 0.000$ \\
\hline condition time & 10 second & pulse height & $\mathrm{mV} 0.025$ \\
\hline equilibrium time & 5 second & & \\
\hline
\end{tabular}

\section{Effect of pH}

The square wave voltammogram of $\left(2.152 \times 10^{-6}\right) \mathrm{M}$ of SNP were investigated at different $\mathrm{pH}$ values (3-10) using the optimum conditions Table 1 in phosphate buffer. The peak current (Ip) and the peak potential (Ep) obtained are shown in Table 2.

Table 2: Effect of $\mathrm{pH}$ on SWV peak and peak current of $\left(2.152 \times 10^{-6}\right) \mathrm{M}$ of SNP

\begin{tabular}{|c|c|c|}
\hline $\mathbf{p H}$ & $\mathbf{E p ~ ( v )}$ & $\mathbf{I p}(\mathbf{n A})$ \\
\hline 3 & -0.375 & 104.1 \\
\hline 4 & -0.428 & 123.2 \\
\hline 5 & -0.475 & 142.3 \\
\hline 6 & -0.528 & 166.2 \\
\hline 7 & -0.588 & 185.7 \\
\hline 8 & -0.648 & 175.6 \\
\hline 9 & -0.703 & 160.7 \\
\hline 10 & -0.752 & 133.3 \\
\hline
\end{tabular}

The peak current (Ip) is clearly dependent on $\mathrm{pH}$. Maximum current response was found at $(\mathrm{pH}=7.0)$.On the other hand the peak potential (Ep)is found to be greatly dependent on $\mathrm{pH}$ and moves to more negative with increasing the $\mathrm{pH}$ values. Linear plot of Ep versus $\mathrm{pH}$ was obtained in Fig 3 with slope $(-0.0547 \mathrm{~V} / \mathrm{pH})$ and $(\mathrm{R}=0.9995)$ which is very near to the theoretical value obtained by Hammett $(0.059 \mathrm{~V} / \mathrm{pH})(\mathrm{Hammett}, 1940)$. 


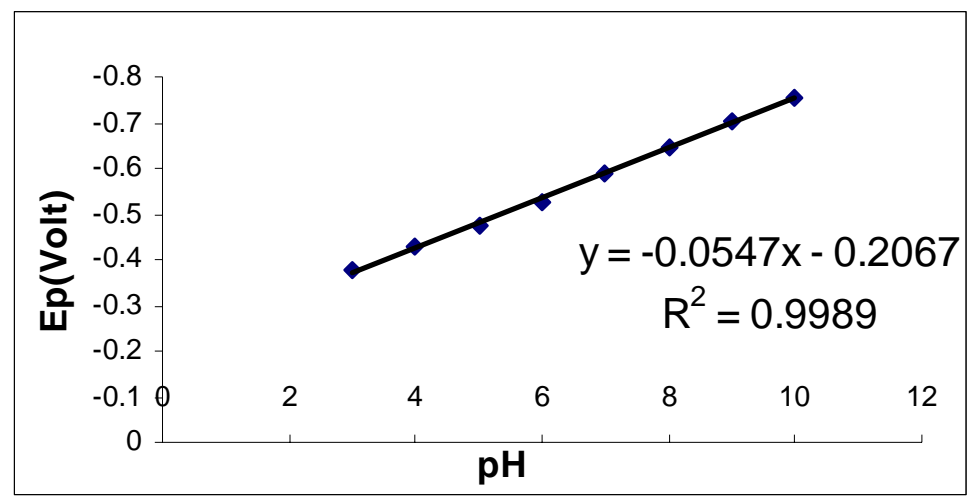

Fig. 3: The relation between Ep and $\mathrm{pH}$ of $\left(2.152 \times 10^{-6}\right) \mathrm{M}$ of Sodium Nitroprusside.

\section{Stability of SNP in aqueous phosphate buffer at $(\mathrm{pH}=7.0)$}

The square wave voltamogram of $\left(3.1 \times 10^{-6}\right) \mathrm{M}$ of SNP were recorded at different time in phosphate buffer at $(\mathrm{pH}=7)$. The results obtained are tabulated in table 3 .

Table 3: Effect of time on SWV peak of $\left(3.1 \times 10^{-6}\right) \mathrm{M}$ of SNP at $(\mathrm{pH}=7.0)$ in aqueous solution.

\begin{tabular}{|c|c|}
\hline Time (min) & Ip (nA) \\
\hline 3 & 250.0 \\
\hline 6 & 252.1 \\
\hline 9 & 254.0 \\
\hline 12 & 253.1 \\
\hline 15 & 256.4 \\
\hline 18 & 260.7 \\
\hline 21 & 253.2 \\
\hline 24 & 249.1 \\
\hline 27 & 263.4 \\
\hline 30 & 264.3 \\
\hline 33 & 255.2 \\
\hline 36 & 257.0 \\
\hline
\end{tabular}

It can be seen from the Table 3 that SNP is stable for more than 36 minute.

\section{Analytical Consideration}

Using The optimum conditions shown in Table 1, the calibration curve were constructed using a serial dilution of a standard SNP in aqueous-phosphate buffer $(\mathrm{pH}=7.0)$ $(5 \mathrm{ml})$. Some typical results are listed in Table 4 . These solutions were prep-ared by adding appropriate aliquots of standard SNP to the phosphate buffer $(5 \mathrm{ml})$ at $(\mathrm{pH}=7.0)$. 
Table 4: Effect of concentration on peak current of $\left[\left(0.398 \times 10^{-6}\right)-\left(8.424 \times 10^{-6}\right)\right] \mathrm{M}$ of SNP at $(\mathrm{pH}=7.0)$ in aqueous solution at $\mathrm{Ep}=-0.588 \mathrm{~V}$.

\begin{tabular}{|c|c|}
\hline Conc. $(\mathbf{M}) \mathbf{1 0}^{\mathbf{- 6}}$ & Ip (nA) \\
\hline 0.398 & 21.4 \\
\hline 0.793 & 52.0 \\
\hline 1.185 & 86.0 \\
\hline 2.152 & 171.8 \\
\hline 3.100 & 237.2 \\
\hline 4.030 & 308.0 \\
\hline 4.942 & 294.7 \\
\hline 5.838 & 345.9 \\
\hline 6.716 & 948.0 \\
\hline 7.578 & 1330.0 \\
\hline 8.424 & 1720.0 \\
\hline
\end{tabular}

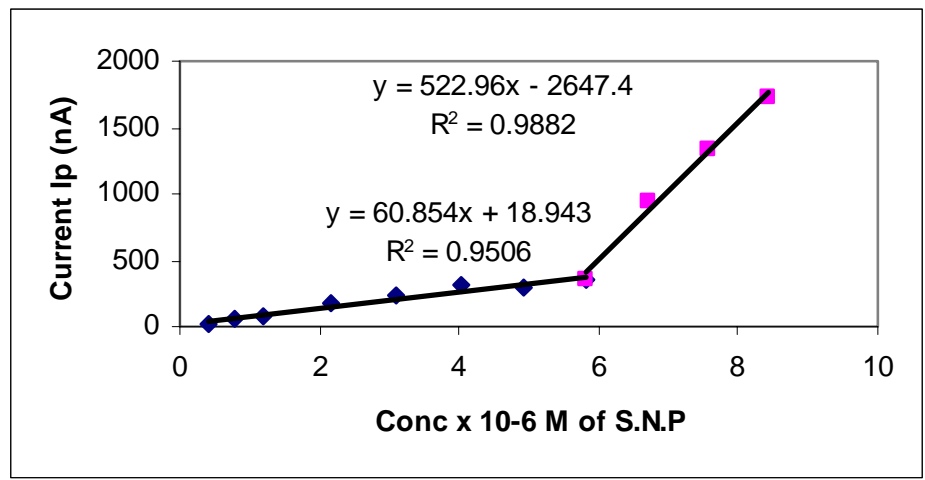

Fig. 4: The relation between peak current (Ip) and concentration of SNP at ( $\mathrm{pH}=7.0)$ phosphate buffer in aqueous solution.

The plot peak current Ip versus molar concentration of SNP is shown in Fig. 4. Regression analysis on standard indicated two straight lines, the first one with concentration range $\left[\left(3.98 \times 10^{-7}-5.838 \times 10^{-6}\right)\right] \mathrm{M}$ with correlation coefficient $(\mathrm{R}=0.9751)$. The second with the concentration range $\left[\left(5.838 \times 10^{-6}-8.4 \times 10^{-6}\right)\right] \mathrm{M}$ with correlation coefficient $(\mathrm{R}=0.9941)$. This behavior maybe due to the change of rate of diffusion with concentration and increase gradually with increasing conc. It well known that the rat of discharge (reduction) depend mainly on the rate of diffusion. The lowest experimental determination limit was $\left(3.9 \times 10^{-7}\right)$.

\section{Voltammetric Behavior of SNP in the Presence of Albumin}

The square wave voltammogram of $\left(9.9 \times 10^{-6}\right) \mathrm{M}$ of SNP in phosphate buffer at $(\mathrm{pH}=7.0)$ was recorded at $(295 \mathrm{~K})$. Successive amounts of albumin $\left(10^{-5}\right) \mathrm{M}$ were then added and the square wave voltammogram were recorded after each addition. The results are shown in Table 6. The peak current Ip of SNP were found to decrease gradually with the 
addition of albumin. This behavior due to the interaction of SNP with albumin. The plot $\mathrm{Ip} / \mathrm{Ip}_{0}$ versus concentration of albumin added is shown in Fig. 5 where $\left(\operatorname{Ip}_{0}=1447.12 \mathrm{nA}\right)$ is the peak current of SNP only without albumin. From which the results of binding constant K of SNP with albumin was then calculated using quadratic equation where $\mathrm{K}$ obtained from the tangent.

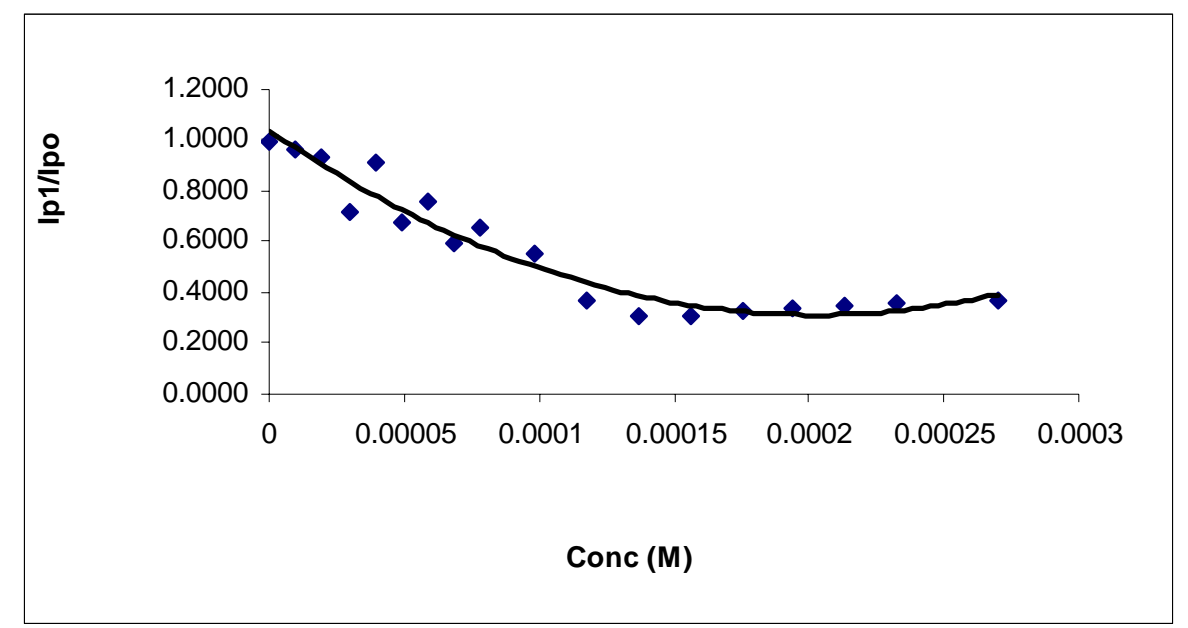

Fig . 5: The plot of $\mathrm{Ip} / \mathrm{Ip}_{0}$ versus the concentration of albumin added.

\section{The effect of temperature on the interaction of Sodium Nitroprusside with albumin}

The square wave voltammogram of $\left(9.9 \times 10^{-6}\right) \mathrm{M}$ of SNP in the presence of albumin (successive addition) were recorded at different temperatures $(295-315) \mathrm{K}$, using the optimum conditions shown in Table 5. The variation of peak current Ip at different temperature are shown in Tables (6-10). The binding constant $\mathrm{K}$ for the interaction of SNP with albumin was calculated and tabulated in Table 11. The Vant's hoff plot of log K versus 1/T gave a straight line Fig. 6 from which the thermodynamic parameters were calculated as follows: $\Delta \mathrm{H}$ from the relation slope $=-$ Slope $\times \mathrm{R} ; \Delta \mathrm{G}=-2.303 \mathrm{R} \mathrm{Log} \mathrm{K}$ and from the Gibbs equation $\Delta \mathrm{S}$ was calculated $(\Delta \mathrm{G}=\Delta \mathrm{H}-\mathrm{T} \Delta \mathrm{S})$. The values of tend for $\Delta \mathrm{H}, \Delta \mathrm{G}$ and $\Delta \mathrm{S}$ are tabulated in Table 12.

Table 5: The optimum condition of binding SNP with albumin.

\begin{tabular}{|c|c|}
\hline Conditions & Value \\
\hline Deposition time & 30 Second \\
\hline Condition time & 5 Second \\
\hline Equilibrium time & $5 \mathrm{Second}$ \\
\hline Frequency & $120 \mathrm{~Hz}$ \\
\hline Scan increment & $2 \mathrm{mV} / \mathrm{second}$ \\
\hline Condition potential & $0.000 \mathrm{~V}$ \\
\hline Pulse height & $0.02 \mathrm{mV}$ \\
\hline
\end{tabular}


Table 6: The peak current of $\left(9.9 \times 10^{-6}\right) \mathrm{M}$ SNP in the presence of different amount $\left(10^{-5}\right) \mathrm{M}$ of albumin in phosphate buffer $(\mathrm{pH}=7.0),\left(\mathrm{Ip}_{0}=1447.12 \mathrm{nA}\right)$ at $295 \mathrm{~K}^{\circ}$.

\begin{tabular}{|c|c|c|}
\hline Conc $(\mathbf{M}) \times \mathbf{1 0}^{-8}$ & $\mathbf{I p}(\mathbf{n A})$ & $\mathbf{I p} / \mathbf{I p}_{\mathbf{0}}$ \\
\hline 0.00 & 1447.12 & 1.0000 \\
\hline 0.09 & 1390 & 0.9605 \\
\hline 1.90 & 1340 & 0.9287 \\
\hline 2.90 & 1044 & 0.7214 \\
\hline 3.90 & 1330 & 0.9156 \\
\hline 4.90 & 984 & 0.6800 \\
\hline 5.90 & 1094 & 0.7560 \\
\hline 6.80 & 868 & 0.5998 \\
\hline 7.90 & 948 & 0.6551 \\
\hline 9.80 & 798 & 0.5514 \\
\hline 11.70 & 528 & 0.3649 \\
\hline 13.60 & 442 & 0.3054 \\
\hline 15.50 & 450 & 0.3110 \\
\hline 17.50 & 472 & 0.3262 \\
\hline 19.40 & 485 & 0.3351 \\
\hline 21.30 & 503 & 0.3476 \\
\hline 23.20 & 518 & 0.3580 \\
\hline 26.90 & 537 & 0.3711 \\
\hline
\end{tabular}

Table 7: The peak current of $\left(9.9 \times 10^{-6}\right) \mathrm{M}$ SNP in the presence of different amount $\left(10^{-5}\right) \mathrm{M}$ of albumin in phosphate buffer $(\mathrm{pH}=7.0),\left(\mathrm{Ip}_{0}=1223 \mathrm{nA}\right)$ at $300 \mathrm{~K}^{\circ}$.

\begin{tabular}{|c|c|c|}
\hline Conc $\mathbf{( M )} \times \mathbf{1 0}^{-\mathbf{8}}$ & $\mathbf{I p}(\mathbf{n A})$ & $\mathbf{I p} / \mathbf{I} \mathbf{p}_{\mathbf{0}}$ \\
\hline 0.0 & 1223.0 & 1.0000 \\
\hline 1.9 & 1127.0 & 0.9215 \\
\hline 3.9 & 948.0 & 0.7751 \\
\hline 5.9 & 743.0 & 0.6075 \\
\hline 7.8 & 464.0 & 0.3794 \\
\hline 9.8 & 326.3 & 0.2666 \\
\hline 11.7 & 321.8 & 0.2631 \\
\hline 13.6 & 366.9 & 0.3000 \\
\hline 15.5 & 405.3 & 0.3314 \\
\hline 17.5 & 426.0 & 0.3483 \\
\hline 19.4 & 456.0 & 0.3729 \\
\hline 21.3 & 476.0 & 0.3892 \\
\hline
\end{tabular}


Table 8: The peak current of $\left(9.9 \times 10^{-6}\right) \mathrm{M}$ SNP in the presence of different amount $\left(10^{-5}\right) \mathrm{M}$ of albumin in phosphate buffer $(\mathrm{pH}=7.0),\left(\mathrm{Ip}_{0}=869.0 \mathrm{nA}\right)$ at $305 \mathrm{~K}^{\circ}$.

\begin{tabular}{|c|c|c|}
\hline Conc $(\mathbf{M}) \times \mathbf{1 0}^{-8}$ & $\mathbf{I p}(\mathbf{n A})$ & $\mathbf{I p} / \mathbf{I p}_{\mathbf{0}}$ \\
\hline 00.0 & 869.0 & 1.0000 \\
\hline 1.9 & 752.0 & 0.8654 \\
\hline 3.9 & 476.0 & 0.5478 \\
\hline 5.9 & 269.8 & 0.3105 \\
\hline 7.8 & 239.7 & 0.2758 \\
\hline 9.8 & 215.8 & 0.2483 \\
\hline 11.7 & 210.5 & 0.2422 \\
\hline 13.6 & 271.8 & 0.3128 \\
\hline
\end{tabular}

Table 9: The peak current of $\left(9.9 \times 10^{-6}\right) \mathrm{M} \mathrm{SNP}$ in the presence of different amount $\left(10^{-5}\right) \mathrm{M}$ of albumin in phosphate buffer $(\mathrm{pH}=7.0),\left(\mathrm{Ip}_{0}=778 \mathrm{nA}\right)$ at $310 \mathrm{~K}^{\circ}$.

\begin{tabular}{|c|c|c|}
\hline Conc $\mathbf{( M )} \times \mathbf{1 0}^{-\mathbf{8}}$ & $\mathbf{I p}(\mathbf{n A})$ & $\mathbf{I p} / \mathbf{I p}_{\mathbf{0}}$ \\
\hline 0.0 & 778 & 1.0000 \\
\hline 1.9 & 660 & 0.8483 \\
\hline 3.9 & 500 & 0.6427 \\
\hline 5.9 & 398 & 0.5116 \\
\hline 7.8 & 300 & 0.3856 \\
\hline 9.8 & 280 & 0.3599 \\
\hline 11.7 & 250 & 0.3213 \\
\hline 13.6 & 186 & 0.2391 \\
\hline 15.5 & 161 & 0.2071 \\
\hline
\end{tabular}

Table 10 : The peak current of $\left(9.9 \times 10^{-6}\right) \mathrm{M}$ SNP in the presence of different amount $\left(10^{-5}\right) \mathrm{M}$ of albumin in phosphate buffer $(\mathrm{pH}=7.0),\left(\mathrm{Ip}_{0}=768.0 \mathrm{nA}\right)$ at $315 \mathrm{~K}^{\circ}$.

\begin{tabular}{|c|c|c|}
\hline Conc $(\mathbf{M}) \times \mathbf{1 0}^{-\mathbf{8}}$ & $\mathbf{I p}(\mathbf{n A})$ & $\mathbf{I p} / \mathbf{I p}_{\mathbf{0}}$ \\
\hline 0.0 & 768.0 & 1.0000 \\
\hline 0.9 & 737.0 & 0.9596 \\
\hline 1.9 & 447.0 & 0.5820 \\
\hline 3.9 & 298.0 & 0.3880 \\
\hline 5.9 & 262.8 & 0.3422 \\
\hline 7.8 & 199.1 & 0.2592 \\
\hline 9.8 & 170.0 & 0.2214 \\
\hline 11.7 & 155.0 & 0.2018 \\
\hline 13.6 & 135.0 & 0.1758 \\
\hline 15.5 & 121.0 & 0.1569 \\
\hline 19.4 & 99.2 & 0.1292 \\
\hline
\end{tabular}


It's very clear from the results in tables (6-10) the peak current of SNP in all concentration decrease with the addition of albumin (due to the interaction ), in the other words, the peak current of SNP in the absence of albumin found to decrease with increasing temperature due to the diffusion process of SNP. The binding constant $\mathrm{K}$ of the interaction between SNP and albumin at different temperature are shown in Table 11.

Table 11: The binding constant $\mathrm{K}$ of the interaction between SNP with albumin at different temperature.

\begin{tabular}{|c|c|c|c|}
\hline Temp. (T) K & $\mathbf{1} / \mathbf{T}$ & $\mathbf{K}$ & $\mathbf{L o g} \mathbf{K}$ \\
\hline 295 & 0.003389 & 0.3179 & -0.497709 \\
\hline 300 & 0.003333 & 0.2755 & -0.559878 \\
\hline 305 & 0.003278 & 0.2199 & -0.657774 \\
\hline 315 & 0.003174 & 0.1110 & -0.954677 \\
\hline
\end{tabular}

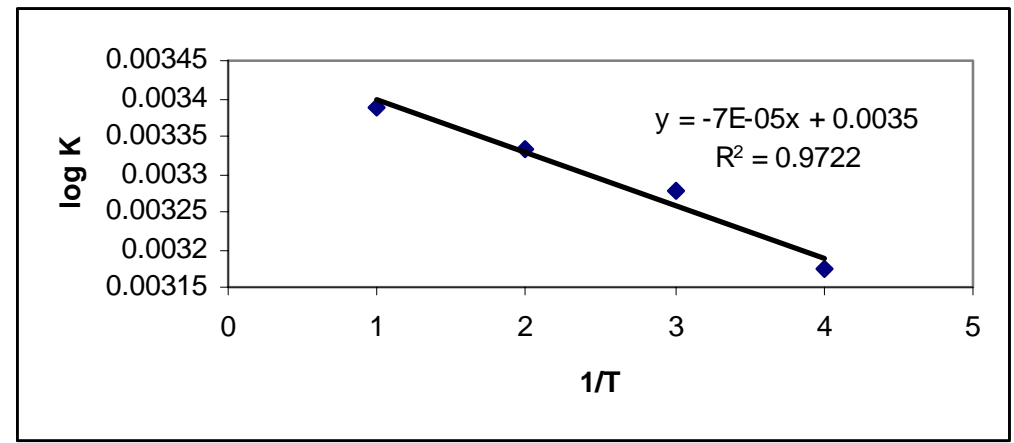

Fig. 6: The relation between $\log \mathrm{K}$ (binding constant) against 1/T.

From the results in the Table (11) It's found that the binding constant $\mathrm{K}$ decrease with increasing temperature. From which the thermodynamic quantities of the interaction of SNP with albumin can be calculated as shown in Table 12.

Table 12 : The thermodynamic quantities of the interaction of SNP with albumin.

\begin{tabular}{|c|c|c|c|}
\hline Temp. $\left(\mathbf{K}^{\circ}\right)$ & $\mathbf{\Delta H}(\mathbf{K J} / \mathbf{m o l e})$ & $\boldsymbol{\Delta} \mathbf{G}(\mathbf{K J} / \mathbf{m o l e})$ & $\boldsymbol{\Delta S}\left(\mathbf{K J} / \mathbf{m o l e .}^{\circ}\right)$ \\
\hline 295 & $18.667-$ & 2.8112 & -0.0728 \\
\hline 300 & $=$ & 3.2160 & -0.0729 \\
\hline 305 & $=$ & 3.8413 & -0.0737 \\
\hline 315 & $=$ & 5.7579 & -0.0775 \\
\hline
\end{tabular}

The negative values of $\Delta \mathrm{S}$ indicate that the complexes formed after the interaction of SNP-albumin is more ordered. The negative values of $\Delta \mathrm{H}$ indicate that the process of interaction is exothermic. The low and positive values of $\Delta \mathrm{G}$ indicate that the interaction is of the type ion-ion (Bohinski, 1987). 


\section{REFERENCES}

Butler, A. R.; Megson, I. L . (2002). Non - Heme Iron Nitrosyls In Biology. Chemical Reviews 102,1155-1165.doi:10.1021/cr 0000 76d.

Baaske, D. M.; Smith, M. D.; Karnatz, N. ; Carter, J. E. (1981). High-performance liquid chromatographic determination of sodium nitroprusside. J. Chromatogr .7 ; 212(3), 339- 46.

Bohinski, R. C. (1987). "Modern Concept in Biochemistry". 5th edn., Allyn and Bacon, Inc., Massachusetts, 38p.

Coppens, P.; Novozhilova, I.; Kovalevsky, A. (2002). Photoinduced Linkage Isomers of Transition -Metal Nitrosyl compounds and Related complexes . Chem . Rev. 102, 861-883. doi:10.1021/cr 000031c.

Frank, M. J.; Johnson, J. b.; Rubin, S. H. (1976). Spectrophotometric determination of sodium nitroprusside and its photo degradation products. J. Pharm. Sci.; 65(1),44-8.

Hammett, L.P. (1940). " Physical Organic Chemistry". Mc Graw-Hill, New York. pp.184199.

Helena, M.; Carapuca, J.; Simao, E. J.; Arnold, G. F. ,(1996). Electrochemistry of the nitroprusside ion . From mechanistic studies to electrochemical analysis. J. Analyst. 121, 1801-1804

http://www.medicinenet.com/sodium nitroprusside-injection/article.html (2005).

http://www.netdoctor.co.uk/medicines/100002418.html (2004).

Navaza, A.; Chevrier, G.; Alzari , P. M.; Aymonino, P. J. (1989). Single-crystal neutron diffraction structure of sodium penta cyano nitrosyl ferrate (2-) (sodium nitroprusside) dehydrate. Actacryst. 45(6),839841.doi:10.1107/5010827018803691

Rauhala, P.; Khald, A.; Mohanakumar, K.P.; Chiueh, C. C. (1998). Apparent role of hydroxyl radicals inoxidative brain injury induced by sodium nitroprusside. Free Radical Biol. Med. 24, 73-1065. 